\title{
FOLIAR TREATMENT WITH PROLINE AND TYROSINE AFFECT THE GROWTH AND YIELD OF BEETROOT AND SOME PIGMENTS IN BEETROOT LEAVES
}

\author{
M. Rashad EL-SHERBENY*1, Jaime A. TEIXEIRA DA SILVA**2 \\ ${ }^{1}$ Botany Department, National Research Centre, El-Tahrir St., El-Dokki, Cairo, Egypt \\ ${ }^{2}$ P. O. Box 7, Miki-cho post office, Ikenobe 3011-2, Kagawa-ken, 761-0799, Japan
}

Received: July 11, 2013; Accepted: September 17, 2013

\begin{abstract}
There is interest in increasing the yield and pigment content of beetroot and red beet since conventional agronomic practices or breeding efforts have not produced satisfactory results. Using a local cultivar of red beet (Beta vulgaris L. subsp. cicla) as the model plant, pot experiments were established to determine the effects of proline and tyrosine (used as plant growth regulators and for synthesis of beetroot pigments) on growth and yield and pigment (carotenoids and chlorophyll) levels in leaves. Proline or tyrosine at 100 and $200 \mathrm{mg} \cdot \mathrm{L}^{-1}$ increased plant height, number of leaves, fresh and dry weight of leaves and roots, root/shoot ratio, and root diameter and length while a higher concentration $\left(400 \mathrm{mg} \cdot \mathrm{L}^{-1}\right)$ increased some parameters but decreased others. Any proline concentration resulted in more leaf carotenoids and chlorophyll and higher carbohydrate content in leaves and roots than the controls, and tyrosine was more effective than proline. Tyrosine and proline proved to be successful agents in improving growth and yield characters of beet plants, especially at $100 \mathrm{mg} \cdot \mathrm{L}^{-1}$ and $200 \mathrm{mg} \cdot \mathrm{L}^{-1}$. Beetroot growers can effectively use these two amino acids as a foliar application to increase yield for edible purposes and to increase pigments for extraction for use in coloring and medicinal industries.
\end{abstract}

Key words: Beta vulgaris, chlorophylls, carotenoids, proline, tyrosine, vegetative growth, yield

\section{INTRODUCTION}

Beta vulgaris L. subsp. conditiva (Chenopodiaceae) roots contain significant amounts of antioxidants (Wettasinghe et al. 2002) while the leaves of subsp. cicla are an excellent source of vitamin A and are also high in folate, soluble and insoluble dietary fibre and antioxidants (Zielińska-Przyjemska et al. 2009). Beetroot owes its color to a variety of betalain pigments, including betanin, obetanin, probetanin and neobetanin (red to violet pigments are collectively known as betacyanin). Other pigments found in it are indicaxanthin and vulgaxanthins (yellow to orange pigments known as betaxanthins) (Eastwood \& Nyhlin 1995).

According to Hess (1981), proline and tyrosine are the starting materials for the synthesis of beetroot pigments, betacyanins and betaxanthins.
Amino acids have been shown to improve growth and yield of plants: $11.51 \mathrm{mg} \cdot \mathrm{L}^{-1}$ proline on Zea mays L. (Hamed \& El-Wakeel 1994), $25 \mathrm{mg} \cdot \mathrm{L}^{-1}$ alanine or tyrosine on peppermint (Mentha piperita) (Refaat \& Naguib 1998) and 100, 200 or $400 \mathrm{mg} \cdot \mathrm{L}^{-1}$ ornithine and phenylalanine (Phe) on Datura innoxia Mill. (Habba 2003). Gamal El-Din \& Abd ElWahed (2005) showed that a foliar application of $50 \mathrm{mg} \cdot \mathrm{L}^{-1}$ ornithine and $100 \mathrm{mg} \cdot \mathrm{L}^{-1}$ proline or Phe increased plant height, number of branches, fresh and dry weights of aerial vegetative parts and flower head of chamomile (Matricaria chamomilla L. Rausch). Shukry et al. (2008) reported that asparagine and glutamine benefited Phaseolus vulgaris (L.) grain yield and vegetative characters. Foliar application of glutamine at $100-200 \mathrm{mg} \cdot \mathrm{L}^{-1}$ significantly increased plant height, number of leaves, fresh weight of leaves, fresh and dry weight, leaf 
area, bulb length, bulb diameter and weight, as well as yield of onion and quality of bulbs (Amin et al. 2011).

Bálványos et al. (2002) reported that addition of $66 \mathrm{mg} \cdot \mathrm{L}^{-1}\left(10^{-4} \mathrm{M}\right)$ Phe maximized growth and alkaloid (lobeline) production of hairy root cultures of Lobelia inflata L. A foliar application of Phe at $250 \mathrm{mg} \cdot \mathrm{L}^{-1}$ increased plant height, number of branches, stem diameter, dry weight of shoots, fresh and dry weight of fruits, photosynthetic pigments and capsaicin and dihydrocapsaicin content of pepper (Capsicum annum L.) (Rashad et al. 2002).

This study was undertaken to evaluate the effects of proline and tyrosine, assess their ability to stimulate vegetative growth and yield, and quantify the increase in chlorophylls and carotenes in beetroot leaves.

\section{MATERIALS AND METHODS}

A pot experiment was conducted during two consecutive seasons $(2006 / 2007 ; 2007 / 2008)$ in the greenhouse of the Botany Department, National Research Center, Cairo, Egypt, to study effects of foliar application of proline and tyrosine on growth, yield and production of chlorophylls and carotenoids in a local cultivar of $B$. vulgaris subsp. cicla leaves. Beet seeds were sown in plastic pots of $30 \mathrm{~cm}$ diameter filled with about $10 \mathrm{~kg}$ substrate containing loam, sand and silt $(1: 1: 1, \mathrm{v} / \mathrm{v})$ on 15 October in both seasons. Seedlings were thinned to one seedling per pot. Fertilization of plants was done with $4 \mathrm{~g}$ calcium superphosphate, $4 \mathrm{~g}$ calcium nitrate and $2 \mathrm{~g}$ potassium sulphate per plant, applied in a split manner at 21 and 35 days after sowing. Plants were treated with a $20 \mathrm{~mL}$ per plant foliar application of freshly prepared aqueous solution of the amino acids proline or tyrosine (Sigma-Aldrich, St. Louis, MO) at $0,100,200$ or $400 \mathrm{mg} \cdot \mathrm{L}^{-1}$, thrice. The first application was at 30 days after sowing and the second and third applications at 45 and 60 days after sowing using a hand-held sprayer to completely cover the plant foliage. All treatments were replicated three times (six plants per replicate) and arranged in a completely randomized design. At the full vegetative stage (75 days old), plants were harvested to determine plant height (above-ground level), number of leaves, fresh and dry weights of leaves and roots, root/shoot ratio and root diameter and length. Contents of chlorophyll (chl) $a, \operatorname{chl} b$, total chl $(a+b)$ and that of total carotenoids were determined spectrophotometrically in fresh leaf samples according to Saric et al. (1967). Total carbohydrate content in dried leaves and roots were determined according to Dubois et al. (1956) as follows. Dry samples $(20 \mathrm{mg})$ were placed in a test tube and extracted in a boiling water bath successively with 10 and $5 \mathrm{~mL}$ of $\mathrm{NaOH}$. After $10 \mathrm{~min}, 5 \mathrm{~mL}$ of distilled water was added to the extracted protein content. The residue was washed with water and extracted twice at room temperature for $30 \mathrm{~min}$ with $10 \mathrm{~mL}$ of $57 \%$ $\mathrm{H}_{2} \mathrm{SO}_{4}$. Samples were diluted and filtered to eliminate cell particles. Then $1 \mathrm{~mL}$ of $5 \%$ phenol reagent was added to $1 \mathrm{~mL}$ of filtered and diluted sample, and $5 \mathrm{~mL}$ of concentrated $\mathrm{H}_{2} \mathrm{SO}_{4}$ was added. The mix was left to stand for $30 \mathrm{~min}$ at room temperature. The resulting color was measured at $490 \mathrm{~nm}$ using a spectrophotometer against a reagent blank and total carbohydrates were calculated using a standard curve of glucose using 18 replicates per treatment.

Data for the two seasons were combined due to lack of significant differences between them. Least significant differences were calculated according to Snedecor and Cochran (1982). Data were analysed by one-way ANOVA and means separated with Duncan's multiple range test.

\section{RESULTS}

\section{Growth and yield characters}

Treatment with proline at 100 and $200 \mathrm{mg} \cdot \mathrm{L}^{-1} \mathrm{im}$ proved plant height, number of leaves, fresh and dry weight of leaves and roots, root/shoot ratio and root diameter and length (Table 1). Fresh weight of roots increased by 54 and $22 \%$ over controls when proline was applied at 100 and $200 \mathrm{mg} \cdot \mathrm{L}^{-1}$, respectively. Number and fresh weight of leaves decreased at $400 \mathrm{mg} \cdot \mathrm{L}^{-1}$. Tyrosine was more effective than proline in increasing vegetative growth of plants, especially at $100 \mathrm{mg} \cdot \mathrm{L}^{-1}$. Tyrosine at $100 \mathrm{mg} \cdot \mathrm{L}^{-1}$ produced the tallest plants with the greatest number of leaves, heaviest fresh and dry weights of leaves and roots, and roots with the highest diameter and length (Table 1). 
Table 1. Effect of proline and tyrosine concentrations on growth and yield characters of beet plant. Combined analysis of two seasons $(n=18)$

\begin{tabular}{lccccccccc}
\hline \multirow{2}{*}{$\begin{array}{c}\text { Amino acid } \\
\text { concentration } \\
\left(\mathrm{mg} \cdot \mathrm{L}^{-1}\right)\end{array}$} & \multicolumn{10}{c}{ Growth and yield characters } \\
\cline { 2 - 10 } & $\mathrm{PH}^{\mathrm{b}}$ & LN & LFW & LDW & RFW & RDW & R/S & RD & RL \\
\hline Control $^{\mathrm{a}}$ & 21.83 & 9.77 & 30.66 & 3.77 & 85.35 & 11.30 & 2.59 & 4.83 & 5.34 \\
Proline 100 & $25.07^{*}$ & $12.68^{*}$ & $47.03^{*}$ & $6.54^{*}$ & $131.02^{*}$ & $18.92^{*}$ & $2.78^{*}$ & $6.80^{*}$ & $6.62^{*}$ \\
Proline 200 & $23.31^{*}$ & $11.57^{*}$ & $36.71^{*}$ & $5.37^{*}$ & $104.13^{*}$ & $14.99^{*}$ & $2.78^{*}$ & $6.25^{*}$ & $5.82^{*}$ \\
Proline 400 & $22.49^{*}$ & 9.16 & 29.06 & $4.20^{*}$ & 83.55 & $12.80^{*}$ & $2.88^{*}$ & 5.53 & 5.65 \\
Tyrosine 100 & $27.13^{*}$ & $13.10^{*}$ & $49.22^{*}$ & $7.37^{*}$ & $134.62^{*}$ & $21.97^{*}$ & $2.72^{*}$ & $7.08^{*}$ & $6.56^{*}$ \\
Tyrosine 200 & $24.47^{*}$ & $11.38^{*}$ & $40.23^{*}$ & $5.75^{*}$ & $122.33^{*}$ & $17.96^{*}$ & $3.06^{*}$ & $6.72^{*}$ & $6.32^{*}$ \\
Tyrosine 400 & $23.06^{*}$ & 9.97 & $32.06^{*}$ & $4.63^{*}$ & 87.62 & $13.26^{*}$ & $2.74^{*}$ & 5.39 & $6.19^{*}$ \\
\hline
\end{tabular}

* Significantly different from control at $P \leq 0.05$, DMRT

${ }^{\text {a }}$ Control $=$ no amino acid application

${ }^{\mathrm{b}} \mathrm{PH}=$ plant height $(\mathrm{cm}), \mathrm{LN}=$ leaf number, LFW $=$ leaf fresh weight $\left(\mathrm{g} \cdot \mathrm{plant}^{-1}\right), \mathrm{LDW}=$ leaf dry weight $\left(\mathrm{g} \cdot\right.$ plant $\left.^{-1}\right), \mathrm{RFW}=$ root fresh weight $\left(\mathrm{g} \cdot\right.$ plant $\left.^{-1}\right), \mathrm{RDW}=$ root dry weight $\left(\mathrm{g} \cdot \mathrm{plant}^{-1}\right), \mathrm{R} / \mathrm{S}=$ ratio of root $/$ shoot fresh weight, $\mathrm{RD}=$ root diameter $(\mathrm{cm}), \mathrm{RL}=$ root length $(\mathrm{cm})$

Table 2. Effect of proline and tyrosine concentration on leaf pigments (relative ratio) and carbohydrate percentage in beetroot. Combined analysis of two seasons $(n=18)$

\begin{tabular}{cllcccc}
\hline $\begin{array}{c}\text { Amino acid } \\
\text { concentration } \\
\left(\mathrm{mg} \cdot \mathrm{L}^{-1}\right)\end{array}$ & $\mathrm{Chl} a^{\mathrm{b}}$ & $\mathrm{Chl} b$ & $\mathrm{TChl}$ & Carotenoids & LC & RC \\
\cline { 2 - 7 } Control & 0.42 & 0.17 & 0.59 & 0.41 & 16.20 & 28.40 \\
Proline 100 & $0.52^{*}$ & $0.21^{*}$ & $0.72^{*}$ & $0.50^{*}$ & $19.90^{*}$ & $36.20^{*}$ \\
Proline 200 & $0.48^{*}$ & $0.19^{*}$ & $0.67^{*}$ & $0.46^{*}$ & 17.80 & $32.10^{*}$ \\
Proline 400 & $0.45^{*}$ & 0.17 & $0.62^{*}$ & 0.41 & 16.90 & $30.20^{*}$ \\
Tyrosine 100 & $0.54^{*}$ & $0.20^{*}$ & $0.74^{*}$ & $0.50^{*}$ & $20.40^{*}$ & $35.50^{*}$ \\
Tyrosine 200 & $0.51^{*}$ & 0.18 & $0.68^{*}$ & $0.48^{*}$ & $19.30^{*}$ & $33.40^{*}$ \\
Tyrosine 400 & 0.47 & 0.18 & $0.65^{*}$ & $0.45^{*}$ & 17.20 & $31.20^{*}$ \\
\hline
\end{tabular}

* Significantly different from control at $P \leq 0.05$, DMRT

${ }^{\text {a }}$ Control $=$ no amino acid application

${ }^{\mathrm{b}} \mathrm{Chl} a=$ chlorophyll $a, \mathrm{Chl} b=$ chlorophyll $b, \mathrm{TChl}=$ total chlorophylls $(a+b)$, carotenoids = total carotenoids, $\mathrm{LC}=$ leaf carbohydrates $(\%), \mathrm{RC}=$ root carbohydrates $(\%)$. Pigment content assessed from fresh matter; carbohydrate content based on dry matter

\section{Leaf pigments and carbohydrate content}

Plants treated with proline and tyrosine contained more leaf pigments (chl $a$ and $b$, total chl and carotenoids), except for proline at $400 \mathrm{mg} \cdot \mathrm{L}^{-1}$ and higher carbohydrate content in roots than the control (Table 2).

\section{DISCUSSION}

In arid and semi-arid countries such as Egypt there is a need to increase yields of important horticultural crops without use of excessive fertilization. Use of amino acids and cheap and biodegradable chemicals as foliar applications has been shown to 
been shown to increase yield and agronomic performance of several crops, as exemplified next. In beet, use of tyrosine and proline could be effectively employed to increase yield and pigment production. Proline at different concentrations has been shown to simulate growth and yield of Nicotiana rustica L. (Darwish \& Reda 1975), cotton Gossypium barbadense (Heikal \& Shaddad 1982), corn Zea mays L. (Hamed \& Al-Wakeel 1994), tomato Solanum lycopersicum L. (Abd El-Latif 1995; Ragab et al. 2001), Matricaria chamomilla L. Rausch (Gamal El-Din \& Abd El-Wahed 2005), and Urtica pilulifera (L.) (Wahba et al. 2007). This is likely due to the N-content of these amino acids, even though their metabolic functions are different. Even at high concentrations of either amino acid $\left(400 \mathrm{mg} \cdot \mathrm{L}^{-1}\right)$, no growth parameters were suppressed (Table 1).

Proline plays a regulatory role in activity and function of the enzymes catalase, peroxidase and polyphenol oxidase in plant cells and in their participation in development of metabolic responses to environmental factors (Öztürk \& Demir 2002). The proposed functions of accumulated proline are osmoregulation, maintenance of membrane and protein stability, growth, seed germination while carbon and nitrogen serve as an energy store (Hare et al. 2003). Refaat \& Naguib (1998) and Wahba et al. (2007) reported a positive effect on $U$. pilulifera growth and yield parameters following tyrosine application. L-Tyrosine, an aromatic amino acid, is not only used for the synthesis of proteins, but also serves as an important precursor for natural products, including pigments, alkaloids, and hormones (Maeda \& Dudareva 2012). Refaat \& Naguib (1998) added that application of tyrosine increased total carbohydrate content of peppermint (Mentha piperita L.) leaves. A mixture of amino acid fertilizers improved grain yield of common wheat (Triticum aestivum L.) (Dromantienè et al. 2013). Ali \& Hassan (2013) also found that the application of a mixture of amino acids could improve several yield-related properties and pigment content of $T a$ getes erecta.

Proline and tyrosine applied as plant growth regulators on leaves increase growth parameters and beetroot leaf pigments - carotenoids and chlorophylls. This can be used in practice as a simple but effective way to increase yield and improve the agronomic quality of this vegetable. It remains to be studied whether such treatments would also increase the betacyanin content.

\section{REFERENCES}

Abd El-Latif A.M. 1995. Physiological studies on tomato. MSc thesis, Faculty of Agriculture, Cairo University, Cairo, Egypt.

Ali E.F., Hassan F.A.S. 2013. Impact of foliar application of commercial amino acids nutrition on the growth and flowering of Tagetes erecta L. plant. J. Appl. Sci. Res. 9: 652-657.

Amin A.A., Gharib F.A.E., El-Awadi M., El-Sherbeny M.R. 2011. Physiological response of onion plants to foliar application of putrescine and glutamine. Sci. Hortic. 129(3): 353-360. DOI: 10.1016/j.scienta.2011.03.052

Bálványos I., Szõke É., Kursinszki L. 2002. The influence of amino acids on the lobeline production of Lobelia inflata L. hairy root cultures. Plant Growth Regul. 36: 241-244.

Darwish S.M., Reda F. 1975. Effect of lysine and proline on alkaloidal content of Nicotiana rustica L. in relation to growth and flowering. In: Proc. 14th Conference of Pharmaceutical Science, Cairo, Egypt.

Dromantienė R., Pranckietienė I., Šidlauskas G., Pranckietis V. 2013. Changes in technological properties of common wheat (Triticum aestivum L.) grain as influenced by amino acid fertilizers. Zemdirbyste-Agriculture 100: 57-62. DOI 10.13080/z-a.2013.100.008

Dubois M., Gilles K.A., Hamilton J.K., Rebers P.A., Smith F. 1956. Colorimetric method for determination of sugars and related substances. Anal. Chem. 28: 350-356. DOI: 10.1021/ac60111a017

Eastwood M.A., Nyhlin H. 1995. Beeturia and colonic oxalic acid. QJM - Int. J. Med. 88: 711-717.

Gamal El-Din K.M., Abd El-Wahed M.S.A. 2005. Effect of some amino acids on growth and essential oil content of chamomile plant. Int. J. Agric. Biol. 7: 376-380.

Habba E.E.L. 2003. The role of amino acids ornithine and phenylalanine in growth, chemical constituents and alkaloidal contents in Datura innoxia Mill. J. Agr. Sci., Mansoura Univ. 26: 1261-1268. 
Hamed A.A., Al-Wakeel S.A. 1994. Physiological response of Zea mays exposed to salinity and to exogenous proline. Egypt. J. Bot. 34: 93-105.

Hare P.D., Cress W.A., van Staden J. 2003. A regulatory role for proline metabolism in stimulating Arabidopsis thaliana seed germination. Plant Growth Regul. 39: 491-500.

Heikal M.M.D., Shaddad M.A. 1982. Alleviation of osmotic stress on seed germination and seedling growth of cotton, pea and wheat by proline. Phyton 22: $275-287$.

Hess D. 1981. Plant physiology. Molecular, biochemical and physiological fundamentals of metabolism and development. Narosa Publishing, New Delhi.

Maeda H., Dudareva N. 2012. The shikimate pathway and aromatic amino acid biosynthesis in plants. Annu. Rev. Plant Biol. 63: 73-105. DOI: 10.1146/annurev-arplant-042811-105439

Öztürk L., Demir Y. 2002. In vivo and in vitro protective role of proline. Plant Growth Regul. 38: 259-264.

Ragab M.E., Helal R.M., Khalaf S.M., Hafez M.R. 2001. Improving productivity of tomato under saline conditions by proline or manganese foliar spray. Ann. Agric. Sci., Ain Shams Univ. 46: 773-784.

Rashad E.S.M., Habba E.E.L., Farahat M.M. 2002. Growth, fruiting and active ingredient of hot pepper plants as affected by phenylalanine, cinnamic acid and coumaric acid. Egypt. J. Appl. Sci. 17: 698-715.

Refaat A.M., Naguib N.Y. 1998. Peppermint yield and oil quality as affected by application of some amino acids. Bull. Fac. Agric., Cairo Univ. 49: 89-98.
Saric M., Kastrori R., Curic R., Cupina T., Gric I. 1967. Chlorophyll determination. University of "Noveon Sadu Praktikum iz Fiziologize Biljaka”, Belgrade, Serbia.

Shukry W.M., Haroun S.A., El-Sawy O. 2008. Asparagine and glutamine affect the growth and cause metabolic changes in Phaseolus vulgaris in vivo. Middle Eastern \& Russian J. Plant Sci. Biotech. 2: 9-28.

Snedecor G.W., Cochran W.G. 1982. Statistical methods. Oxford and IBH Publishing Co. 7th ed. Iowa State Univ. Press, Ames, Iowa.

Wahba H.E., Motawe H.M., Ibrahim A.Y., Mohamed A.H. 2007. The influence of amino acids on productivity of Urtica pilulifera plant. In: 3rd International Conference of Pharmaceutical and Drug Industries Division, National Research Council, Cairo, Egypt.

Wettasinghe M., Bolling B., Plhak L., Xiao H., Parkin K. 2002. Phase II enzyme-inducing and antioxidant activities of beetroot (Beta vulgaris L.) extracts from phenotypes of different pigmentation. J. Agric. Food Chem. 50: 6704-6709.

Zielińska-Przyjemska M., Olejnik A., Dobrowolska-Zachwieja A., Grajek W. 2009. In vitro effects of beetroot juice and chips on oxidative metabolism and apoptosis in neutrophils from obese individuals. Phytother. Res. 23: 49-55. 